\title{
Transculturalism as Conveyed in Kiran Desai's The Inheritance of Loss
}

\author{
Selma Valeska Adriana \& Ira Rasikawati \\ selma.2014ude002@civitas.ukrida.ac.id\&iraras@ukrida.ac.id \\ Department of English , Universitas Kristen Krida Wacana, Jakarta
}

\begin{abstract}
This study presents an analysis of cultural values and the idea of transculturalism as conveyed in The Inheritance of Loss, a novel written by Kiran Desai. The novel portrays the euphoria of globalization and the cultural issues faced by Indian immigrants in the West. Through her main characters Jemubhai, Biju, and Sai - Desai implies her idea of transculturalism. The characters' journey through the post-colonial era in different cultural settings offers insights into how the characters negotiate the differences between cultures and contexts. This study critically analyzed the characters' attitudes from the hybridity theory perspective to unravel the author's voice about transculturalism. The three analysis stages performed were to determine key story elements associated to the transcultural theme, to classify the evidence supporting the theme emerged, and to interpret the findings using the new historicism approach and in view of the hybridity theory. In response to the two questions raised on what cultural values inferred from the characters' view and what idea of transculturalism conveyed through the author's voice, this study found that the characters offered differing perspectives on cultural permeation and blending. The author suggested the consequences of resistance to cultural diversity.
\end{abstract}

Keywords: transculturalism, hybridity, post-colonialism

\section{Introduction}

Literature can seldom escape from cultural contexts. Significant interests have been devoted to studying the relationship between literature and its cultural contexts to date. In Indonesia, the challenge of pluralism has been prevalent due to the integrated cultures (Sari, 2017). Various cultures, religions, and ethnic groups flourished in Indonesia reflect the country's diversity. The emergence of new cultures is a result of the cultural mixing that occurs in this country (Sari, 2017). These new cultures are not inherited from Indonesian native ancestors, but they have been part of Indonesian cultures. As globalization era begins, more cultures have met and become even more diverse than ever. The idea that cultures meet and develop from its singular state remarks the presence of transculturalism. By studying the transculturalism in the literary work of other cultures, this study was expected to inspire future Indonesian writers to raise transculturalism issues into their work as well as to encourage further discussion into the issue within the contexts of literature in Indonesia and other cultures.

Transculturalism is a term first used by Fernando Ortiz Fernandez to denote the notion of converging cultures (Jaidka, 2012). Transculturalism becomes inevitable as globalization allows cultural interaction which results in cultural diversity. The idea that globalization does involve cultural interaction is further supported by the study of UNESCO (2009) which implies that globalization is closely related to cultural diversity. In line with Welsch (2009) who suggests that the idea of singular culture is no longer relevant, this study raises the topic of transculturalism as 
conveyed in literature. Desai's The Inheritance of Loss confirms the argument of Jaidka (2012) that transculturalism can serve as an approach to literature and that literature provides much scope for transcultural studies.

English literature has been used to deliver people's voice since the colonization era (Burney, 2012). In line with this idea, the current study analyzed the author's voice on transculturalism in light of Bhabha's hybridity theory. Kiran Desai's The Inheritance of Loss views transculturalism from the globalization perspective which can be related to colonialism. This portrayal is inspired by Desai's experience as she states that her characters' journeys are the reflection to her own journey and the idea that she wants the readers to capture of what it is like to live between the East and West (Golla, 2012).

This study answers two questions concerning the cultural values and the idea of transculturalism in Kiran Desai's The Inheritance of Loss. The first question is, what cultural values are inferred from the characters' view? While the second question is, what idea about transculturalism is conveyed through the author's voice? Using the evidence that emerged from the characters' traits, behaviors, and/or action, this study aims to identify the cultural values of the characters. It further describes the author's voice on transculturalism.

Cultures are the core point of transcultural literature (Jaidka, 2012). The interactions between cultures are supposedly in line with understanding (Tamcke, 2013). If these interactions are restricted, tensions may heat up between cultures. Many things can occur unexpectedly due to cultural interactions, suggesting the situation we live in today; where cultures meet and get mixed up. Cultural interaction suggests that transculturalism is not something that can be done or stopped as it is a reality and part of human life (Tamcke, 2013).

The fact that colonization occurs mostly in the Asian countries does not mean that transculturalism only exists in Asia. De Salazar (2013) argues that transculturalism is a recent cultural phenomenon that also occurs in
Ireland, suggesting that transculturalism also exists in Europe. When immigrants came, many new languages and cultures influenced Irish people's way of life. De Salazar (2013) states that transculturalism has changed people's way of defining nationality. De Salazar reviews the works of two Irish writers, Roddy Doyle and Hugo Hamilton. Roddy Doyle produces several short stories with the theme of diversity in Ireland (de Salazar, 2013). While Doyle humorously implies the need of deconstructing as being fully traditional Irish is no longer valid, Hugo Hamilton tells stories about himself facing the confusion of different cultures in his own family (de Salazar, 2013).

Regaining national identity can be achieved by using the work of literature (Burney, 2012). In her study, Burney argues that English literature has become a voice of the colonized countries since the colonization era. The voice from non-English writers through English literature is considered important as it is a part of regaining their country's national identity (2012). English itself has become a widely-used language of literature that makes it a cross-cultural product (Bhabha, 1994). Suzuki (2006) also argues that English literature helps to recollect cultural pieces from the past that are part of a country's national identity. English and its widespread use have made countries stay connected. Therefore, examining literary works such as English novels can serve an approach to view transculturalism through international authors' voice.

Suzuki (2006) presents an analysis of globalization and transculturalism in Minae Mizumura's Honkaku Shosetsu. Mizumura suggests that Japanese literature should be constructed following the globalization era (Suzuki, 2006). Mizumura and Desai share a similarity in that both are immigrants who raise the issue of transculturalism. Mizumura (2006) reveals that Japanese literature is no longer pure Japanese as it has been affected by Western values in writing. Like other transcultural novels that address a specific issue and time, Minae Mizumura's Honkaku Shosetsu views the situation of post-World War II when Japan has a strong connection with America. Through the connection, different cultures - East and West are met. The 
cultural hybridity has become an important part and even an identity in many Japanese literary works (Suzuki, 2006).

Kiran Desai's The Inheritance of Loss is reviewed as a work that portrays the struggle of finding one's identity in the modern world. Some studies have analyzed Kiran Desai's The Inheritance of Loss in the post-colonialism perspective but not through the transculturalism lens. Chandramani and Reddy (2013) review Kiran Desai's The Inheritance of Loss as a work about the life of immigrants in America. The effect of globalization has brought people to work or study abroad. The immigrant life that Kiran Desai presents in her story appears to be closely related to hybridization as it involves the crossing of two different cultures.

Andersson (2014) suggests that hybridization takes place when cultural boundaries are crossed. Hybridization can lead to transculturalism as cultural contact occurs. Transculturalism consists of the integration of different cultures due to the breaking down of cultural boundaries (Grosu, 2012). Kiran Desai's The Inheritance of Loss appears to illustrate hybridization as the characters experience living in a transcultural environment. This study focuses on the analysis of the characters and author's voice in the story related to transculturalism. It investigates the characters' view of the different cultures: the West and the East. Through the comparison between different cultures, the occurrence of identity crisis is observed. Golla's study (2016) suggests identity crisis is portrayed in the characters of Kiran Desai's The Inheritance of Loss in that they suffer from the post-colonial dilemmas such as mimicry, double consciousness, and ambivalence.

Kiran Desai's The Inheritance of Loss shows the euphoria of the globalization and the bitter life of immigrants. Kantamma (2017) analyzes the characters of Kiran Desai's The Inheritance of Loss as the subjects to hybridization and identity crisis. A study conducted by Najila (2013) suggests that Kiran Desai's The Inheritance of Loss illustrates the colonialism effects in a globalized world. Bala (2013) similarly states that the effects of globalization in immigrants' life are shown in the characters' struggles. Najila (2013) argues that Kiran Desai's The Inheritance of Loss renews the notion of post-colonialism in that the issues experienced by the novel's characters are related to the past colonization. Kiran Desai's The Inheritance of Loss shows the bitter truth of the present society. Racial stereotypes, which lead to discrimination, become discouragement for the immigrants as they try to adapt and live in the West (Kantamma, 2017).

The literary theories used in the analysis are those suggested by Bennett and Royle (2016). The theories of author's voice and character are employed to analyze Desai's idea about transculturalism. Aldama (2011) argues that character analysis is one of many literary methods to understand a literary text or the author's voice. The analysis of the characters' cultural values and author's voice centers in the characters' journey which can be seen through the cultural negotiation experienced by each character. Allolio-Nacke (2014) argues that transculturalism focuses on cultural transition and cultural negotiation.

Bhabha's theory of hybridity (1994) suggests that cultural negotiations in establishing new cultural identities are caused by the situation in which cultures meet and transform each other. This situation is the portrayal of transculturalism which allows people to negotiate in adapting and integrating cultures (Kraidy, 2005). This cultural interaction, however, leads to cultural issues (Bhabha, 1994) which are often acknowledged as post-colonial dilemmas such as mimicry, ambivalence, and double consciousness (Golla, 2016). Furthermore, Bhabha (1994) argues that these post-colonial dilemmas can lead to an identity crisis.

Transculturalism is usually described in the light of hybridity (Helff, 2012). Kraidy (2005) also presents his logic of transculturalism in globalization by using hybridity theory to explain the fact that cultures are now hybrid. He asserts that the cultural issues in today's world are the transformation from the cultural imperialism to the cultural globalization. This transformation is the relation between 
globalization and colonialism in transculturalism (2005). Considering that transcultural practices are influenced by the experiences of migration, transculturalism is the most influential concept to describe cultural contact (Helff, 2012).

In a globalized world, where cultures meet and interact, cultural values are also being shared within the society. Cultural values, according to Smith and Bond (1994), refer to universal statements about what we think is desirable or attractive (Smith \& Bond, 1994, as cited in Kim \& Omizo, 2014). Cultural values are also the aspiration and desire that inspire people to behave (Trompenaars \& HampdenTurner, 1998). The cultural values discussed in this study are the generally believed Western and Indian cultural values. The classification of Asian cultural values by Kim and Omizo's (2014) include values such as collectivism, interdependence, respecting family members, and harmony. Among the American-European or the Western cultural values suggested by Kim and Omizo (2014) identified in the novel are individualism, independence, separateness, and freedom or 'the sky is the limit'.

The characters' traits, behaviors and/or action are three elements of the characters used to identify the characters' cultural values. The Indian cultural values centered at family tradition (Sonia et al., 2006). Upholding family is an important Indian cultural value (2006), which is in line with the common Asian values of collectivism and respect for family members (Kim \& Omizo, 2014). Indian people also tend to look modest because they highly appreciate traditional cultures. This implies that Indian people still live with the concept of traditional cultures (Sonia et al., 2006).

Other important aspects of Indian cultural values are religion, education, and tolerance (Sonia et al., 2006). Indian people highly respect their religious practices. Education is also perceived as important in Indian families, which show the influence of colonialism (Vadekar, 2002). Getting in touch with the British makes Indian people consider knowledge or education as its main goal to build a respectful family (2002). However, education is still a problem in India as not all people have access to it (Sonia et al., 2006).

The Western cultural values presented in this study are of the English and the American. Hewitt (2009) suggests English cultural values involve independence, privacy, freedom, fairness, politeness, tolerance, being pragmatic and realistic, and respecting personal space. According to Kohls (1984), the American cultural values center at the individual desire and development. He classifies thirteen American cultural values that are easily recognized by foreigners - personal control, change, time and its control, equality, individualism and privacy, self-help concept, competition and free enterprise, future orientation, action/work orientation, informality, directness, openness and honesty, practicality and efficiency, and materialism/acquisitions (1984).

\section{Methodology}

This study employed a critical qualitative analysis to examine Kiran Desai's The Inheritance of Loss. Critical qualitative research is a critique of social and cultural aspects that have limited us to think freely of this world (Merriam, 2009). It focuses on the context of literature and highlights the social issues. Critical qualitative research may raise questions about the influence and intersections of race, class, and gender. It covers the cause and effect of particular issues in the society (2009).

Desai's The Inheritance of Loss views the intersections between different cultural backgrounds; race and class. These cultural interactions were explained by using the hybridity theory to study situations in which cultural boundaries were crossed. As the novel brings up the memory of the past colonialism in the globalization era (Chandramani \& Reddy, 2013), the New Historicism approach is used to unravel the cultural values, issues, and themes of transculturalism related to the impacts of past colonialism. The New Historicism is considered as an appropriate approach to examine a literary work from the past reconstruction in present perspective (Ukkan, 2002). 
Since the novel portrays the cultural diversity and interactions through the characters' journeys (Golla, 2016), this study examined the characters' struggles in establishing their cultural identity. Desai describes her characters narratively and through the dialogues among the characters. Links between the characters cultural values and the ideas of transculturalism were studied. The analysis of the characters served as the initial step to understanding the author's voice.

Three major steps were followed to analyze the novel. The first step was an analysis of the three characters - Jemubhai, Biju, and Sai. The analysis focused on the characters' traits, behaviors, and/or action to identify their cultural values. The New Historicism approach was employed to identify the characters' internal conflicts and post-colonial dilemmas which contribute to shaping their cultural values. The second step was classifying the evidence which supports the central themes that emerged in the character analysis. The labels assigned were associated with the authors' voice on transculturalism. The third step was interpreting the themes and labels identified in light of the hybridity theory and other critics' arguments.

\section{Character Analysis \\ 1. Jemubhai}

Jemubhai, or the judge, is "a retired member of the judiciary." (Desai, 2006, p. 18). Jemubhai is a character who refuses to integrate cultures because he desires to establish an English identity. His experience of being an immigrant has changed him to be a westernized person. Jemubhai tries to mimic the English people by trying to look like them (p. 174), dress like them (p. 185), and speaks English every day. Desai usually italicizes Indian words, but the author never italicizes the words Jemubhai speaks. Mimicry appears to be a post-colonial dilemma which Jemubhai experiences to establish an English identity as evident in the following citation:

He worked at being English with the passion of hatred and for what he would become, he would be despised by absolutely everyone, English, and Indians, both" (p. 126).

The character analysis of Jemubhai suggests that the cultural values inferred in him are those of the English. Intellectualism is a Western cultural value that Jemubhai tried to achieve when he was studying in Cambridge. He worked hard to pass the test and succeed as the first Indian student studying in Cambridge (p. 124). Other values are individualism, independence, separateness, and privacy. Individualism and separateness are two Western cultural values (Kim \& Omizo, 2014) which are in line with English cultural values of independence and privacy (Hewitt, 2009).

The values of individualism, independence, separateness, and privacy are recognized in Jemubhai's relationship with his family. After Jemubhai's return to India, he becomes distant and ignorant to his family ( $p$. 174). He thinks that the Indians are thieving and ignorant people. He even treats his wife badly only because she is an Indian. "In public, he never spoke to or looked in her direction" ( $\mathrm{p}$. 176).

His distant relationship suggests that Jemubhai adopts privacy as his cultural value. It is further supported by the fact that Jemubhai never talks to his wife of his life or takes her to his business trip (p, 178). Desai portrays the family situation scene that shows us the value 'separateness' as seen in Jemubhai's family gathering. Desai writes the thought of Jemubhai who feels that he is a foreigner while trying to separate himself from the family in the middle of the gathering ( $\mathrm{p}$. 173). Collectivism and respecting family members are Asian cultural values which are in line with the Indian cultural value that upholds family. Desai writes that Jemubhai made a long journey to jettison his family's prayers, which makes him realized that he has abandoned his family (p. 308). The absence of Jemubhai's interaction with his family implies his distant-being and that he does not contribute to collectivism, respecting family members, and upholding family.

Jemubhai's ignorance towards his family suggests that he adopts individualism and 
independence. It is further supported by his father's statement. "It was a mistake to send you away. You have become like a stranger to us" (p. 312).

His father suggests that Jemubhai has separated himself from the family. Saying that his own son is a stranger implies that Jemubhai has changed his way of life different from his family. In response to his father's statement, Desai narrates Jemubhai's thought of being a stranger to his own country:

The judge could live here, in this shell, this skull, with the solace of being a foreigner in his own country (p. 36).

This narration implies that the solace of being a foreigner or a stranger makes Jemubhai happy which results from his desire to separate himself from the Indians.

Desai infers that trying to become an English man has made Jemubhai gets despised. Jemubhai seems to be despised as he disavows his own origin cultures and only allows English cultures to be permeated within himself. Jemubhai's preference for the culture and how he experiences cultural negotiation are displayed in his journey. Desai describes Jemubhai's journey to England as an experience that ended painfully as she writes:

"Many years had passed, and yet the day returned to him vividly, cruelly" (p. 42).

Desai uses the word 'cruel' when describing Jemubhai's memory of his past, suggesting that his experience as an immigrant is somewhat painful. Furthermore, Desai gives a clue on what happened to Jemubhai in the past through his first encounter with the English people:

The young and beautiful were no kinder; girls held their noses and giggled, "Phew, he stinks of curry! (p. 46)

On page 46, Desai portrays how Jemubhai was treated in England. She explains that no one wanted to sit next to him or even talk to him (p. 46). The fact that people thought of his smell like curry suggests that there is a racial stereotype. Desai writes that Jemubhai realizes that his skin color and strange English accent are the reason why no one wants to get close to him as written below.

Thus Jemubhai's mind had begun to warp; he grew stranger to himself than he was to those around him, found his own skin oddcolored, his own accent peculiar (Desai, 2006, p. 47).

Jemubhai was faced with a racial stereotype which makes him felt strange. The racial stereotype portrayed here relates to skin color which makes Jemubhai think of his skin color odd. Jemubhai's past is crucial in analyzing his response to transculturalism in that the treatment he has got influences his perspective of culture.

Jemubhai's experience of having no acceptance should have given him enough reason to hate the English, but surprisingly, he does not show hatred towards them. In response to having no acceptance in the English society, Jemubhai starts adoring the English people. On page 125 Desai writes, "He envied the English. He loathed Indians" (p. 125).

Jemubhai prefers the English culture to the Indian. He is ashamed of himself as an Indian and looks up to the English. The following citation suggests Jemubhai's growing respect for Queen Victoria and the English.

The more he pondered this oddity, the more his respect for her and the English grew" (p. 66)

This finding supports the idea proposes by Bhabha (1994) that ex-colonized people face a challenge in crossing cultural boundaries, which is an identity issue. Bhabha (1994) argues that people coming from ex-colonized countries tend to show adoration towards the colonizers. Jemubhai's identity as an Indian is challenged when he comes to England. He starts hating the Indians and respecting the English. Jemubhai's rudeness towards the Indians is shown after he returns from England, suggesting his hatred towards Indians (p. 125). Jemubhai tries to look like an English man as seen through his effort to make his skin whiter by powdering his face regularly (p. 173) and applying cologne (p. 40) all over 
his body so he would not be 'smelly'; a stereotype learned from this story. This evidence serves as an example of Jemubhai's effort to mimic the English people.

Desai states that Jemubhai would always prefer the Western cultures and people (p. 126). Jemubhai's preference to English culture suggests that he experiences a sense of ambivalence in that he is attracted to the English and repulsed by the Indians. Jemubhai's ambivalence is also shown in his efforts to establish an English identity (p. 126). Stories of Jemubhai's nostalgia suggest that Jemubhai deals with the issue of identity. Although he is faced with transculturalism which allow the English and the Indian cultures meet and integrate, Jemubhai only allows the English culture to be permeated. The cultural integration therefore never occurs.

Young (2005) argues that identity crisis is a major issue in globalization era. This issue is what the post-colonial dilemmas lead to (Golla, 2016). Desai's description of Jemubhai relies mostly on his past. The result of being permeated into one culture, especially if that culture is not one's origin, is an identity crisis. This study found that Jemubhai's response to transculturalism led him to an identity crisis as supported by the following citation: "He was a foreigner -a foreigner -every bit of him screamed" (p. 173).

\section{Biju}

Biju is another character of The Inheritance of Loss that is also an immigrant. Different from Jemubhai, Biju immigrates to find a well-paid job (p. 28). Biju is originally a man who hates the Pakistanis and adores the Americans. Desai writes that Biju adores people who have harmed India and hates those who have never done.

This habit of hate had accompanied Biju, and he found that he possessed an awe of white people, who arguably had done India great harm, and a lack of generosity regarding almost everyone else, who had never done a single harmful thing in India (p. 83).
Biju's cultural values are those of the Indian including respecting or upholding family, interdependence, and respecting religious practices. Biju's action to banish his anxiety of his father's situation implies that he truly cares for him (p. 236). This suggests that being an immigrant does not make Biju become distant to his father. The fact that Biju still cares for his father suggests that he respects his family. The value 'interdependence' is shown in Biju's dependence on his friend to provide him a shelter (p. 105). Biju's respect for religious practices is evident as he decides to establish himself as a Hindi. His preference for Indian culture suggests his respect for Hinduism. On page 146, Desai writes:

To Biju he said: "Beef? Are you crazy? We are an all-Hindu establishment. No Pakistanis, no Bangladeshis, those people don't know how to cook (p. 146).

Biju decides to work in a place that serves no beef and is Hindu-oriented. As a Hindi, Biju has to respect cows, so he cannot work in a restaurant that serves beef.

During the time Biju becomes an immigrant in America, he learns the American cultural values such as freedom or 'the sky is the limit', individualism, and independence or self-help concept. Although Biju and his friends are illegal immigrants, they can work and live freely in America (p. 153). Biju learns the values individualism and independence or self-help concept' when he needs a shelter after losing a job (p. 105). Being ignored by his friend, Nandu, makes him understand that he needs to survive alone in America (p. 105).

The initial description of Biju that possesses awe to white people supports Bhabha's theory (1994) which argues that crossing cultural boundaries can lead to ambivalence to people coming from excolonized countries. Biju's hatred shows that he has a sense of ambivalence due to the cultural contradiction he faces. The cultural contradiction presented here is the fact that Biju is an Indian but he possesses awe to people who, according to Desai (p. 83), have harmed the Indians. Desai's description of the relationship between the Western people with 
the Indian people shows the impact of globalization. Desai uses the word 'harm' to describe colonization in which the Western people are considered as those who have given Indians a difficult time as inferred from Biju's ambivalence on page 83 .

Biju's experience as an immigrant in America makes him learns about the racial stereotype that dark means dirty (p. 193). This stereotype is similar to the one that Jemubhai finds in England. Biju learns this stereotype due to the treatment he gets from the Americans. Desai uses Biju's experience to show the racial stereotype of judging people by their skin color. Biju's experience describes the unpleasant situation of Indians who become immigrants as Desai writes

It was horrible what happened to Indians abroad and nobody knew but other Indians abroad. It was a dirty little rodent secret. But, no, Biju wasn't done. His country called him again" (p. 145).

His experience makes Biju aware that as an Indian, he cannot expect much in America. Desai uses the word 'horrible' to address the treatment given to the Indians in Western countries. Realizing the horrible treatment, Biju starts to miss his home as Desai writes about him being called by his country. Through Biju's working places, Desai illustrates the social hierarchy which reminds us of colonialism. "On top, rich colonial, and down below, poor native" (p. 28).

Desai portrays the immigrants' life in America through the illustration of Biju's working places, which are European restaurants. The poor native that she mentions refers to the restaurant's servants who come from Asian and African countries. Desai mentions the rich colonial to refer to both the Americans and Europeans. The description of Biju's working places shows how Asian and African immigrants are positioned in America, especially those without legal papers like Biju.

Biju's journey suggests a different perspective in facing cultural diversity. Through Biju's experience as an immigrant, Desai shows how stereotypes can affect people's lives. Biju faces difficulty dealing with people's assumption of him. This experience makes Biju wants to come home (p. 105). Biju's response to transculturalism suggests that he prefers to stay loyal to his origin culture which is the Indian. Similar to Jemubhai, Biju adopts the concept of a singular culture in response to transculturalism but Biju chooses Indian culture to be permeated within him.

\section{Sai}

Sai is a sixteen-year-old orphaned girl who is the granddaughter of Jemubhai. She lived in Russia until her parents were killed in an accident, causing her moving in with Jemubhai in Kalimpong, India. Sai is another character that is being westernized as stated in the following citation:

She was a westernized Indian brought up by English nuns, an estranged Indian living in India (p. 216).

Sai becomes westernized because she lives in an English convent, where she learns Western cultures and is used to those (p. 36). Jemubhai looks at Sai and finds that she is similar to him in terms of accent and manners (p. 216).

Sai adopts several cultural values which are of the Western and Indian. The Western cultural value that Sai adopts is autonomous and freedom whereas the Indian values are harmony and tolerance. The following statement shows Sai's disposition.

If I want to celebrate Christmas, I will, and if I don't want to celebrate Diwali then I won't. Nothing wrong in a bit of fun and Christmas is an Indian holiday as much as any other (p. 169).

Sai does not show any cultural preference. Spielman (2010) argues that Sai responds to the cultural diversity differently from the way Jemubhai does as she places herself between two different cultures without taking the side to one of them. This study finding confirms Spielman's argument in that Sai has accustomed to living between two different cultures without hatred. Sai lived with English nuns in a Catholic convent before she moves to Kalimpong. Desai writes what Sai has learned in the convent, "...cake was better than laddoos, 
fork spoon knife better than hands,... English was better than Hindi" (p. 36).

Sai learns that the English cultures are better than the Indian cultures, despite the fact that she is an Indian. Being taught English cultures does not make Sai take a side. She has an English accent and Western manners because she is used to that. Living with her grandfather does not make her adopt the Indians' customs because her grandfather hates those and prefers Sai to keep her good Western accent and manners (p. 216).

Sai is also a victim of the post-colonial dilemma that Desai creates. Desai describes Sai as a reflection of the contradictions around her (p. 268). This description suggests that Sai is faced with the sense of ambivalence and loss in establishing her cultural identity. Living in a transcultural environment; where she experiences the cultural diversity in her country, she starts to feel the loss. On page 329, Desai writes,

"Shame on myself..." she said... Who was she... She with her self-importance, her demand for happiness..." (p. 329).

Sai's feeling of loss is due to the cultural contradiction that leads to ambivalence. This explains the sense of loss occurs to Sai in that she experiences the challenge of living with different cultures. Sai accepts the fact that cultures are hybrid in that she does not show any preference to cultures nor take a side. Whereas Jemubhai and Biju show preference to one culture, Sai does not. Sai allows cultures to be blended as she accepts both the Indian and English cultures. Gyan, Sai's Nepali tutor, claims that Sai is the only person who allows cultural blending (p. 170). As the only character that shows no preference for one culture over the others, Sai's perspective implies that she believes in the freedom of following any cultures. Sai becomes autonomous as she takes action and judgment based on her belief in freedom.

Harmony and tolerance are seen in Sai's nature. Sai always tries to maintain peace with people although they are against her, especially her cultural perspective. People like Jemubhai and Gyan have shown a preference for one culture and they are against Sai's cultural perspective. The value 'tolerance' is implied through Sai's view of transculturalism, in that she accepts cultural diversity without taking the side of one culture.

\section{Kiran Desai's Voice on Transculturalism}

Kiran Desai's The Inheritance of Loss portrays the situation where cultural boundaries are breaking down and cultural identities are challenged. The characters encounter the situation which allows them to integrate new cultures with their origin cultures. Jemubhai, Biju, and Sai respond to transculturalism differently. Jemubhai and Biju are being permeated by one culture. That one culture, English for Jemubhai and Indian for Biju, dominates their cultural perspective in that they refuse cultural integration. Sai, despite the cultural contradiction around her, is the only character who accepts the idea of transculturalism by allowing cultures to be blended. The description of three characters' journey, especially in adopting cultural values and establishing a cultural identity, conveys Kiran Desai's idea of transculturalism.

The characters analysis suggests that there are two aspects of transculturalism presented in the novel. These two aspects are the cultural permeation and cultural blending. Cultural negotiation occurs within the characters' journeys in that each of the characters must deal with cultural diversity and its challenge in establishing one's cultural identity. The result of this cultural negotiation is different from one character to another. Jemubhai and Biju are two characters who take a side in the cultural permeation, while Sai is in the cultural blending. Their resistance to the cultural integration suggests that Jemubhai and Biju are permeated by one culture. Jemubhai is permeated by the English culture while Biju is by the Indian. Their response leads to cultural issues recognized by Golla (2016) as post-colonial dilemmas which are mimicry, ambivalence, and double consciousness. People who refuse cultural integration can also influence those who do not refuse as seen in Sai's experience. Sai's perspective suggests that she accepts cultural 
diversity and allows cultures to be blended, but she is accused of having that perspective by people who refuse cultural integration.

Kiran Desai, through her novel's characters, infers that transculturalism involves cultural negotiation to deal with. From the struggles and dilemmas faced by the characters, Desai shows that the feeling of loss due to an identity crisis is the consequence of today's transculturalism, especially when one lives with the concept of a singular culture and is permeated by one culture. Desai's characters; Jemubhai and Biju, respond to transculturalism differently from Sai. They both prefer the idea of a singular culture which makes them go through double consciousness, ambivalence, and mimicry. Sai is the character who embraces cultural diversity and allows cultures to be blended although the cultural contradiction around her makes her questions her own cultural identity. The characters analysis has shown how each character's view is changed due to struggles and dilemma he/she faces. Through these three characters, Desai's implies the idea of transculturalism in establishing one's cultural identity. She suggests the importance of embracing cultural diversity in changing not only cultures but also people.

\section{Conclusion}

The three main characters of The Inheritance of Loss are faced with the struggle of establishing a cultural identity. Their cultural values suggest different aspects of transculturalism - cultural permeation and cultural blending. Jemubhai's journey has westernized him in that he grows hatred to the Indians and respect to the English. Biju's journey abroad has made him determined to return to India, maintaining values such as interdependence, respect for family, and religion. Sai is the only character who accepts the cultural diversity without showing any preference. She believes in harmony, tolerance, freedom, and autonomy.

Through the journey of the characters in her novel, Desai shows the importance of understanding transculturalism by accepting cultural diversity. She also shows the consequences for those who refuse cultural integration. The Inheritance of Loss offers a different view of transculturalism, which involves cultural permeation and blending. The characters' journeys suggest that people can choose to allow one culture to be permeated or different cultures to be blended. The characters' experience offers a different point of view in perceiving culture, which allows the readers to capture the idea of transculturalism in the novel. In facing transculturalism and establishing self-identity, one need to be engaged in cultural negotiation and embracing cultural diversity.

\section{References}

Andersson, J. "Of Ambivalence, Anxiety and Acceptance - A Postcolonial Reading of Kiran Desai's The Inheritance of Loss" (Master's Thesis). Gothenburg: University of Gothenburg, 2014.

<https://gupea.ub.gu.se/bitstream/2077 /38268/1/gupa_2077_38268_1.pdf>

Bennett, A., \& Royle, N. An Introduction to Literature, Criticism and Theory. New York, NY: Routledge, 2016.

Bala, S., \& Kumar, G. Conflicting Claims and Multicultural Ethos in Kiran Desai's The Inheritance of Loss. Journal of Literature, Culture \& Media Studies, 9 \& 10. 2013. pp. 79-87. $<$ https://www.inflibnet.ac.in/js/index. php/JLCMS/article/viewFile/1684/ 2158>

Bhabha, H.K. The Location of Culture. London: Routledge, 1994. $<$ faculty.georgetown.edu/irvinem/theory /Bhabha-Locationof Culture-chaps.pd>

Burney, S. CHAPTER TWO: "Edward Said and Postcolonial Theory: Disjunctured Identities and the Subaltern Voice. Counterpoints," 417. 2012. pp. 41-60. <http://www.jstor.org/stable/ 42981699> 
Chandramani., \& Reddy, G.B.K. "Kiran Desai's The Inheritance of Loss: Elements of American Dream and Globalization." IOSR Journal Of Humanities And Social Science, 11(2). 2013. pp. 79-81. $<$ www.Iosrjournals.Org)

Desai, K. The Inheritance of Loss. Canada: Penguin Group, 2006. <http://sangrah.weebly.com/uploads/6/ 8/0/3/6803682/the_inheritance_of_loss_ by_kiran_desai.pdf>

De Salazar, A. A-G. "Envisaging Transcultural Realities through Literature in Europe. The Case of Ireland." In Tamcke, M., de Jong, J., Klein, L., \& van der Waal, M. (eds), Europe - Space for Transcultural Existence?, 2013. pp, 185-194. $<$ www.oapen.org/down load?type= document\&docid=610316>

Golla, K.K (2016). "Facing the Postcolonial Dilemmas: A Study of Kiran Desai's Novel 'The Inheritance of Loss". International Research Journal of Management Sociology \& Humanity, 7(1). 2016. pp. 8492.

<https://www.academia.edu/23508635/ FACING_THE_POSTCOLONIAL_DILEMMA S_A_STUDY_OF_KIRAN_DESAIS_NOVEL_T HE_INHERITANCE_OF_LOSS>

Hewitt, K. Understanding Britain Today, 2009. <https://www.livelib.ru/ book/ 1000564571/about-understand ingbritain-today-karen-hewitt>

Hochschild, J., \& Weaver, V. "The Skin Color Paradox and the American Racial Order." Social Forces, 86(2). 2007, pp. 1-28. (https: <scholar.harvard.edu/jlhochschild/ publications/skin-color-paradox-andamerican-racial-order)

Jaidka, M. "India is my country but the world is my home: Transculturality through literature". Paper presented at the Conference on Applied Interculturality Research. (http://www.parncutt. org/cAIR10/text/ procs/Jaidka_cAIR10.pdf)
Kim, B. S. K., \& Omizo, M. M. (2005). “Asian and European American Cultural Values, Collective Self-Esteem, Acculturative Stress, Cognitive Flexibility, and General Self-Efficacy Among Asian American College Students." Journal of Counseling Psychology. 52(3). 2005. pp. 412-419. doi: 10.1037/0022-0167.52.3.412

Kohls, L.R. Values Americans Live By. 1984. (http://www.bu.edu/isso/files/pdf/Ame ricanValues.pdf)

Merriam, S.B. Qualitative Research, A Guide to Design and Implementation. San Fransisco, CA: John Wiley \& Sons, Inc., 2009.

(Retrieved from https://leseprobe.buch. de/images-adb/f2/46/f2465cf6-b1d14d13-829d-e5c985f6ee5c.pdf)

Sari. "Acculturation and Assimilation in Cultural Diversity." 2017. (http://www.flat-uinjkt. web.id/accultur ation-and-assimilation-in-culturaldiversity/)

Spielman, D.W. "Solid Knowledge" and Contradictions in Kiran Desai's The Inheritance of Loss. Critique, 51,2010. pp. 74-89.

doi: 10.1080/00111610903249872

Trompenaars, T. \& Hampden-Turner, C. (1998). Riding The Waves of Culture. London: Nicholas Brealey Publishing.

UNESCO. Investing in Cultural Diversity and Intercultural Dialogue. 2009. (http://unesdoc.unesco.org/images /0018/001847/184755e.pdf)

Vadekar, D.D. The Indian Traditional Values \& Their Indications for Education in India in the Modern Age of Science \& Technology. Indian Philosophical Quarterly, 29(1\&2), 2002. pp. 117-132. (http://unipune.ac.in/ snc/cssh/ipq/english/IPQ/26-30\%20 volumes/29-2\&3/PDF/29-2\&3-1.pdf) 
Welsch, W. "Transculturality - the Puzzling

Form of Cultures Today". 2009.

(http://www2.uni-jena.de/welsch/

Papers/transcultSociety.html)

Young, R.J.C. Colonial Desire: Hybridity in

Theory, Culture and Race. London:

Routledge, 2005.

(http://robertjcyoung.com/CDContents.

pdf) 